\title{
PERANCANGAN INVERTER FREKUENSI TINGGI SEBAGAI SUPLAI PEMANAS INDUKSI PADA OVEN LISTRIK HEMAT ENERGI
}

\author{
Fajar Kurniawan *), Abdul Syakur dan Agung Warsito \\ Departemen Teknik Elektro, Universitas Diponegoro \\ J1. Prof. Sudharto, SH, Kampus UNDIP Tembalang, Semarang 50275, Indonesia \\ *)E-mail :fajarkur1996@gmail.com
}

\begin{abstract}
Abstrak
Pada era ini kita membutuhkan peralatan elektronik yang hemat dan efisien, contohnya oven. Teknologi oven yang berkembang saat ini adalah menggunakan elemen pemanas jenis coil heater Namun heater jenis ini masih menggunakan daya yang tinggi. Berdasarkan permasalahan tersebut penulis bertujuan untuk mencari solusi pemanasan yang efektif, yaitu menggunakan metode pemanasan induksi sebagai penghasil panas oven. Proses pemanasan secara induksi akan bekerja secara optimal pada frekuensi tinggi sehingga dibutuhkan catu daya yang digunakan untuk mensuplai pemanas induksi tersebut. Pada Penelitian ini dibuat power suplai menggunakan inverter resonan paralel frekuensi tinggi topologi fullbridge dengan piranti pensaklaran menggunakan igbt yang pemicuannya diatur oleh IC TL494. Pengaturan daya dilakukan dengan mengubah frekuensi pemicuan sehingga tidak diperlukan rangkaian tambahan yang menjadikan rangkaian menjadi lebih rumit dan tidak efisien Dari hasil pengujian didapat bahwa sistem yang dirancang dapat bekerja pada tegangan 135 Volt AC $50 \mathrm{~Hz}$. Daya maksimal didapat pada frekuensi resonansi $30 \mathrm{kHz}$ yaitu sebesar $521,1 \mathrm{~W}$. Sistem bekerja paling maksimal pada frekuensi resonansi $30 \mathrm{kHz}$ yaitu dapat membuat beban kerja (oven) mencapai suhu 56,40 ${ }^{0} \mathrm{C}$ dalam waktu 60 menit
\end{abstract}

Kata kunci : IC TL494, IR 2110, Inverter, IGBT IRG4PC5W

\begin{abstract}
In this era we need efficient and efficient electronic equipment, for example ovens. The current oven technology is using coil heater type heating elements. However, this type of heater still uses high power. Based on these problems the author aims to find an effective heating solution, which is using the induction heating method as an oven heat generator. The induction heating process will work optimally at high frequencies so that the power supply needed to supply the induction heater is needed. In this Research, a power supply is used using a fullbridge high frequency parallel resonant inverter with a switching device using IGBT which is set by IC TL494. Power settings are done by changing the triggering frequency so that no additional circuit is needed that makes the circuit more complicated and inefficient. From the test results it was found that the designed system can work at 135 Volt AC $50 \mathrm{~Hz}$ voltage. Maximum power is obtained at $30 \mathrm{kHz}$ resonance frequency which is equal to $521.1 \mathrm{~W}$. The system works best at $30 \mathrm{kHz}$ resonance frequency which can make the workload (oven) reach a temperature of $56.400 \mathrm{C}$ within 60 minutes
\end{abstract}

Keywords: IC TL494, IR 2110, Inverter, IGBT IRG4PC5W

\section{Pendahuluan}

Kebutuhan hidup manusia pada saat ini semakin kompleks, sehingga untuk membantu kehidupan sehari-hari diperlukan teknologi yang praktis, murah dan aman. Kemajuan teknologi ini tentunya tidak hanya bertujuan untuk teknologi itu sendiri melainkan yang lebih penting adalah untuk kesejahteraan manusia. Salah satunya pemanfaatannya adalah dalam bidang industri. Pada salah satu industri yaitu proses pemanggangan ikan. Maka diperlukan suatu alat pemanggang (oven) yang bersifat aman, hemat dan ramah lingkungan [1]
Oven pada umumnya menggunakan pemanas (heater) yang dialiri arus listrik sebagai penghasil panas.[2]. Namun heater oven yang ada di pasaran masih menggunakan daya yang tinggi. Berdasarkan permasalahan tersebut penulis bertujuan untuk mencari solusi pemanasan yang efektif, yaitu menggunakan metode pemanasan induksi sebagai penghasil panas oven

Pemanasan secara induksi adalah sebuah proses pemanasan tanpa adanya kontak fisik antara pemanas dengan benda yang dipanaskan [3]. Berbeda dengan metode pemanasan lain yang harus melalui proses pembakaran kemudian diterapkan ke benda yang 
dipanaskan. Pemanas induksi menghasilkan panas dengan memanfaatkan rugi-rugi histerisis dan arus eddy [4]

Proses pemanasan secara induksi akan bekerja secara optimal pada frekuensi tinggi [5] sehingga dibutuhkan catu daya yang digunakan untuk mensuplai pemanas induksi tersebut

Dalam penelitian ini penulis akan merancang Inverter frekuensi tinggi dengan topologi resonan paralel jembatan penuh (full-bridge paralel resonant inverter) yang dapat menghasilkan listrik bolak balik frekuensi tinggi yang digunakan untuk mensuplai kumparan pemanas pada badan oven. Perbedaan dengan peneliti sebelumnya adalah pada rangkaian Driver yang menggunakan 2 buah IR2110, sedangkan penelitian sebelumnya menggunakan rangkaian Isolasi Trafo Pulsa. Dan juga pensaklaran menggunakan igbt IRG4PC5W sedangkan penelitian sebelumnya menggunakan Mosfet IRF460

\section{Metode}

Perancangan dan pembuatan perangkat keras inverter frekuensi tinggi sebagai catu daya pemanas induksi pada pipa pemanas air ini terdiri dari sumber tegangan AC 1 fasa $135 \mathrm{~V}$, rangkaian kontrol, rangkaian driver, rangkaian penyearah dan rangkaian daya inverter.

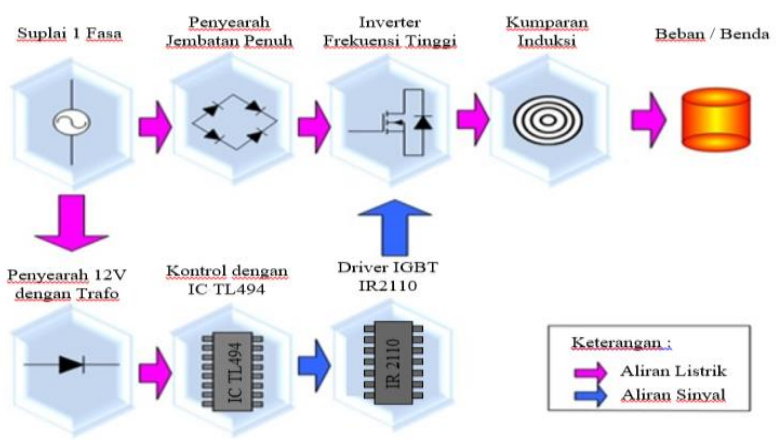

Gambar 1 Blok Diagram Perancangan Alat

\subsection{Perancangan Rangkaian Kontrol}

2.1.1. Rangkaian Penyearah Gelombang Penuh Satu Fasa Teregulasi dengan Center Tap

Rangkaian ini merupakan sumber tegangan DC $12 \mathrm{~V}$ Tegangan 12 VDC berfungsi sebagai suplai untuk rangkaian control IC TL494 dan rangkaian driver IR 2110 Tegangan DC didapatkan dari hasil penyearahan tegangan AC jala - jala yang sebelumnya diturunkan tegangannya menggunakan trafo stepdown dari 220Volt menjadi 12 volt..

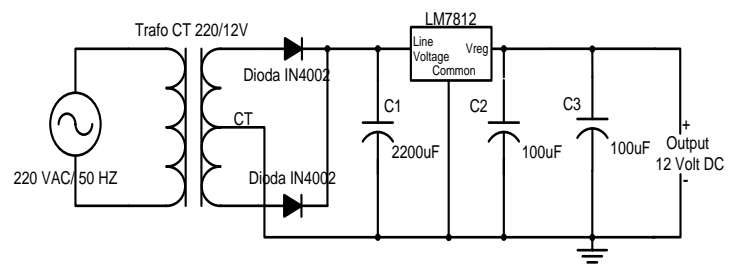

Gambar 2. Penyearah Gelombang Penuh Satu Fasa Teregulasi Dengan Center Tap

Tegangan 12 VAC ketika disearahkan akan menjadi lebih besar yaitu 16,97 VDC, maka hasil keluaran dioda dberikan regulator LM7812 untuk meregulasi tegangan dari $16,97 \mathrm{~V}$ menjadi $12 \mathrm{~V}$.

\subsubsection{Rangkaian Kontrol dengan IC TL494}

Rangkaian kontrol menggunakan IC TL494 berfungsi untuk mengontrol pemicuan IGBT IRG4PC5U pada rangkaian daya inverter. IC TL49 merupakan IC CMOS yang memiliki banyak kegunaan antara lain sebagai penghasil gelombang kotak, astable, dan monostable multivibrator. [6] Untuk menghasilkan picuan gelombang kotak, IC ini difungsikan sebagai astable multivibrator dengan duty cycle 50\%. Pengaturan frekuensi dilakukan dengan mengatur nilai $\mathrm{R}$ dan $\mathrm{C}$.

Pertama-tama kita menentukan frekuensi kerja yang kita inginkan. Penelitian ini dirancang untuk rentang kerja frekuensi $10 \mathrm{kHz}-100 \mathrm{kHz}$. Berdasarkan datasheet IC TL494, pengaturan frekuensinya didapatkan dengan persamaan berikut :

$$
f_{\text {Osc }}=\frac{1}{2 \cdot R_{T} \cdot C_{T}}
$$

Dari persamaan tersebut ditentukan nilai kapasitor yang digunakan sebesar $1 \mathrm{nF}$, maka nilai resistor :

$$
R_{T}=\frac{1}{2 \cdot f_{O s c} \cdot C_{T}}
$$

Untuk f(osc) $\max =100 \mathrm{kHz}$

$$
R_{T}=\frac{1}{2.100 \cdot 10^{3} \cdot 10^{-9}}=5500 \Omega \approx 5600 \Omega
$$

Sedangkan untuk $\mathrm{f}($ osc $) \min =10 \mathrm{kHz}$

$$
R_{T}=\frac{1}{2 \cdot 10 \cdot 10^{3} \cdot 10^{-9}}=55000 \Omega \approx 56000 \mathrm{k} \Omega
$$

Nilai komponen yang ada dipasaran yaitu :

$\begin{array}{ll}\text { CT } & : 1 \mathrm{nF} \\ \text { R: } 5,6 \mathrm{k} \Omega & \\ \text { VR }: 50 \mathrm{k} \Omega\end{array}$

Maka besarnya frekuensi osilator adalah : 
- $\quad$ pada saat $\mathrm{V}_{\mathrm{R}}=0 \Omega$

$f_{\text {OSC(maks) }}=\frac{1}{2.5600 \cdot 10^{-9}}=98,214 \mathrm{kHz}$

- $\quad$ pada saat $\mathrm{V}_{\mathrm{R}}=50 \mathrm{k} \Omega$

$f_{\text {OSC(min) }}=\frac{1}{2.55600 .10^{-9}}=9,892 \mathrm{kHz}$

Dengan demikian untuk memperoleh frekuensi yang diinginkan dapat dilakukan dengan cara mengatur putaran potensiometer $\left(\mathrm{V}_{\mathrm{R}}\right)$. Berikut gambar skema rangkaian kontrol dengan IC TL494 :

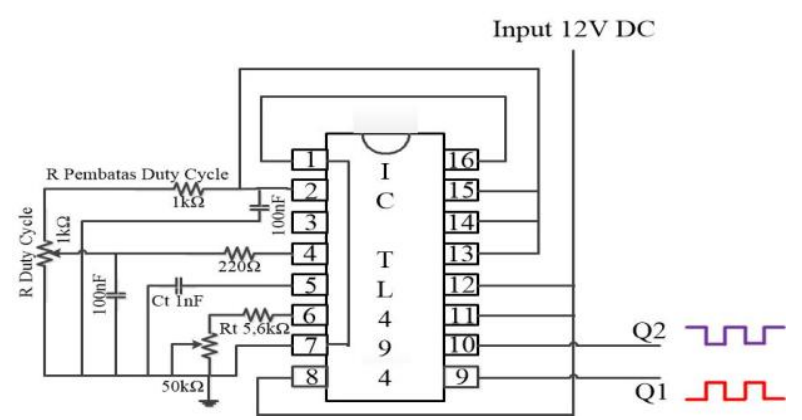

Gambar 3 Rangkaian kontrol dengan IC TL494

\subsubsection{Rangkaian Driver IGBT}

Rangkaian driver IGBT diperlukan untuk memisahkan antara rangkaian daya dengan rangkaian kontrol. Pemisahan ini bertujuan agar ketika terjadi masalah pada rangkaian daya, maka tidak akan sampai merusak rangkaian control [7]. Pada Penelitian ini, digunakan dua buah driver IGBT tipe IR2110 untuk memicu keempat IGBT konfigurasi fullbridge.

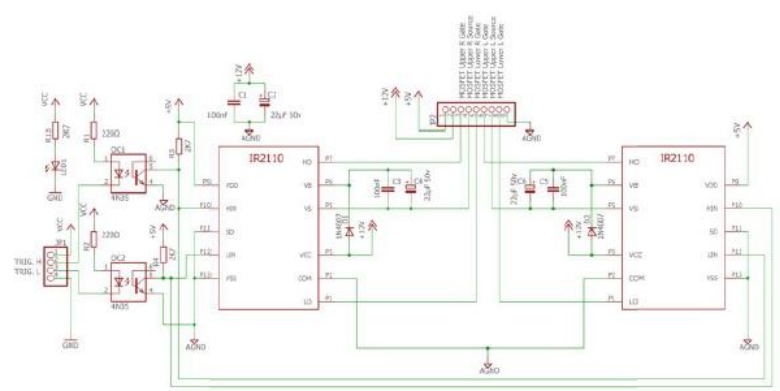

\section{Gambar 4 Diagram skematik driver IGBT IR2110}

\subsection{Perancangan Rangkaian Daya}

\subsubsection{Penyearah Gelombang Penuh}

Penyearah ini digunakan untuk menyearahkan tegangan AC menjadi DC untuk suplai masukan pada rangkaian inverter. Penyearah gelombang penuh ini menggunakan dioda bridge MB3510 yang akan mengubah tegangan 135 VAC menjadi 190,91 VDC dan digunakan kapasitor untuk menghaluskan gelombang keluaran hasil penyearahan.

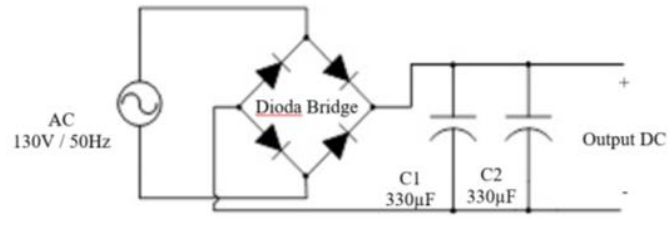

Gambar 5 Rangkaian penyearah gelombang penuh

\subsubsection{Inverter Fullbridge Resonansi Paralel}

Perancangan rangkaian inverter fullbridge resonansi paralel terdiri dari beberapa bagian yaitu rangkaian resonansi paralel dan IGBT.

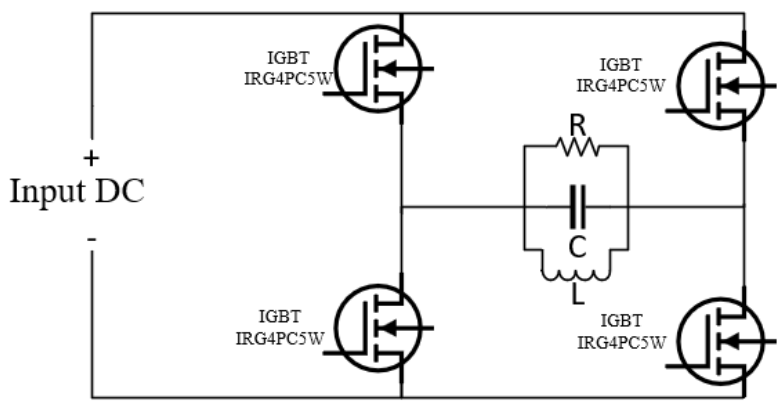

Gambar 6. Inverter fullbridge resonansi paralel

Rangkaian resonansi paralel ini terdiri dari kapasitor dan induktor.

\section{- Induktor}

Kumparan penginduksi dibuat dengan melilitkan kawat tembaga secara spiral. Hal ini karena kumparan penginduksi memiliki fungsi sebagai penginduksi medan magnet ke benda (beban) sehingga diperlukan luasan bidang induksi yang sesuai dengan luasan benda kerja. Hasil dari Kawat tembaga yang telah di lilit didapatkan nilai induktansi sebesar 0.10 $\mathrm{mH}$

\section{- Kapasitor}

Dengan mengetahui frekuensi kerja rangkaian resonansi dan nilai induktor maka dapat diketahui nilai kapasitor yang diperlukan untuk tiap-tiap frekuensi yaitu $30 \mathrm{kHz}, 35 \mathrm{kHz}, 40$ dan $45 \mathrm{kHz}$. Frekuensi tersebut dipilih karena keempat frekuensi tersebut berada diatas batas frekuensi pendengaran manusia . Selain hal tersebut ketuga frekuensi dipilih dengan variasi yang berbeda untuk mengetahui karakteristik sistem terhadap variasi frekuensi Penentuan nilai kapasitor resonansi dapat dicari dengan persamaan berikut :

$f_{0}=\frac{1}{2 \pi \sqrt{L C}}$

Maka nilai $\mathrm{C}$ adalah : 


$$
C=\frac{1}{\left(2 \pi \cdot f_{0}\right)^{2} \cdot L}
$$

Untuk frekuensi $30 \mathrm{kHz}$ maka nilai kapasitor yang dibutuhkan :

$$
\begin{gathered}
C=\frac{1}{\left(2 \pi \cdot 30 \cdot 10^{3}\right)^{2} \cdot 0,1 \cdot 10^{-3}} \\
C=281,733 \mathrm{nF}
\end{gathered}
$$

Untuk frekuensi $35 \mathrm{kHz}$ maka nilai kapasitor yang dibutuhkan :

$$
\begin{gathered}
C=\frac{1}{\left(2 \pi \cdot 35 \cdot 10^{3}\right)^{2} \cdot 0,1 \cdot 10^{-3}} \\
C=206.987 \mathrm{nF}
\end{gathered}
$$

Untuk frekuensi $40 \mathrm{kHz}$ maka nilai kapasitor yang dibutuhkan :

$$
\begin{gathered}
C=\frac{1}{\left(2 \pi \cdot 40 \cdot 10^{3}\right)^{2} \cdot 0,1 \cdot 10^{-3}} \\
C=158,474 \mathrm{nF}
\end{gathered}
$$

Untuk frekuensi $45 \mathrm{kHz}$ maka nilai kapasitor yang dibutuhkan :

$$
\begin{gathered}
C=\frac{1}{\left(2 \pi \cdot 45 \cdot 10^{3}\right)^{2} \cdot 0,1 \cdot 10^{-3}} \\
C=125 \cdot 214 \mathrm{nF}
\end{gathered}
$$

\subsubsection{IGBT}

IGBT (Insulated Gate Bipolar Transistor) adalah suatu komponen elektronika yang difungsikan sebagai saklar. IGBT adalah penggabungan dari keunggulan antara dua komponen yaitu gate control yang sederhana dan kecepatan switching dari MOSFET dan kemampuan aplikasi pada tegangan tinggi serta kemampuan mengalirkan arus yang besar pada Transistor Daya Bipolar [8].

Pada Penelitian ini digunakan IGBT IRG4PC5W dengan spesifikasi sebagai berikut :

\section{Tabel 1. Spesifikasi Igbt IRG4PC5W}

\begin{tabular}{lc}
\hline \multicolumn{1}{c}{ Parameter } & Batas Ambang \\
\hline Tegangan Breakdown Collector - Emitter & $600 \mathrm{~V}$ \\
Tegangan Saturasi Collector - Emitter & $1,65 \mathrm{~V}$ \\
Tegangan Gate - Emitter & $15 \mathrm{~V}$ \\
Arus Kontinu Collector & $55 \mathrm{~A}$ \\
Muatan Total Gate & $270 \mathrm{nC}$ \\
Waktu Tunda On & $46 \mathrm{~ns}$ \\
Waktu Tunda Off & $140 \mathrm{~ns}$ \\
\hline
\end{tabular}

\subsection{Beban Kerja Sistem}

Beban kerja sistem adalah berupa oven dengan ukuran Panjang x lebar x tinggi sebesar $40 \mathrm{~cm} \times 40 \mathrm{~cm} \times 50 \mathrm{~cm}$, lilitan induktor yang berfungsi sebagai kumparan pemanas induksi terletak di sebelah kanan bodi oven.

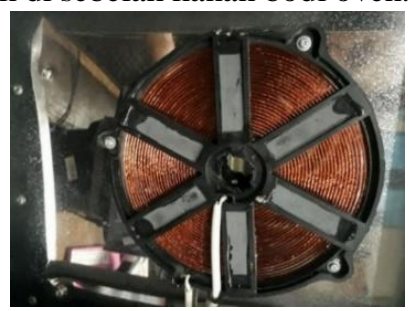

Gambar 7. beban kerja sistem

\section{Hasil dan Analisa}

\subsection{Pengujian Gelombang Keluaran}

Gelombang keluaran rangkaian penyearah dengan CT (center tap) dapat dilihat pada Gambar 8.

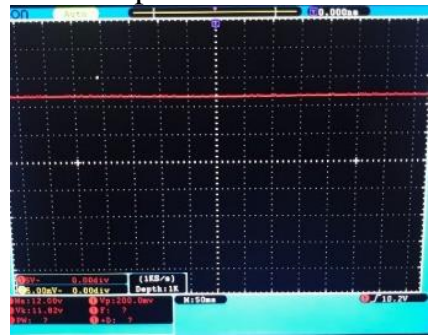

\section{Gambar 8. Gelombang keluaran penyearah dengan CT}

Dari Gambar 8 didapat nilai tegangan 2,4 div pada skala 5 $\mathrm{V} /$ div dengan faktor pengali $1 \mathrm{x}$ sehingga dapat diketahui nilai tegangan DC tersebut adalah sebesar :

$\mathrm{V}=2,4 \operatorname{div} \times 5 \mathrm{~V} / \mathrm{div}$

$$
=12 \text { Volt DC }
$$

Nilai tegangan ini sudah sesuai untuk mensuplai rangkaian kontrol IC TL494.

Gelombang keluaran hasil pengukuran pada rangkaian kontrol IC TL494 dan rangkaian driver isolator pulsa dapat dilihat pada gambar berikut : a. Gelombang IC TL494

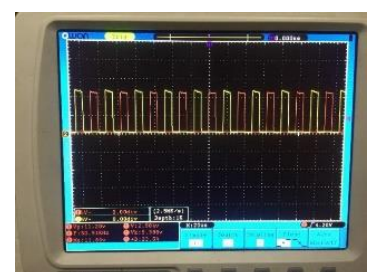

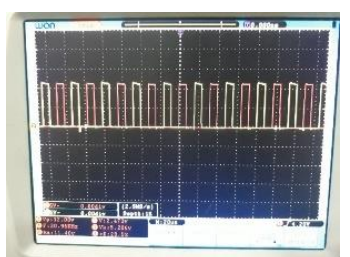

b. Gelombang IR2110

\section{Gambar 9 Gelombang keluaran rangkaian kontrol}

Pada Ganbar 10(a) dapat dilihat tinggi gelombang pemicuan adalah 2,24 div pada skala pengukuran $5 \mathrm{~V} / \mathrm{div}$ dengan faktor pengali $1 \mathrm{x}$ maka dapat diketahui nilai tegangan puncak gelombang tersebut yang digunakan untuk memicu IR2110 adalah sebesar :

$$
\begin{aligned}
\mathrm{V} & =2,24 \operatorname{div} \times 5 \mathrm{~V} / \mathrm{div} \\
& =11.2 \text { Volt } \mathrm{DC}
\end{aligned}
$$


Pada Gambar 9(b) dapat dilihat tinggi gelombang pemicuan adalah 2,4 div pada skala pengukuran $5 \mathrm{~V} /$ div dengan faktor pengali $1 \mathrm{x}$, maka dapat diketahui nilai tegangan puncak gelombang tersebut adalah sebesar :

$$
\begin{aligned}
\mathrm{V} & =2,4 \operatorname{div} \times 5 \mathrm{~V} / \mathrm{div} \\
& =12 \text { Volt } \mathrm{AC}
\end{aligned}
$$

Bentuk gelombang kotak dengan nilai tegangan 12 Volt di gunakan untuk memicu IGBT IRG4PC5W pada rangkaian daya yang mana memiliki nilai tegangan threshold 5 Volt sehingga nilai tegangan pemicuan ini sudah sesuai perancangan.

Gelombang keluaran rangkaian penyearah gelombang penuh blok rangkaian daya dapat dilihat pada Gambar 10.

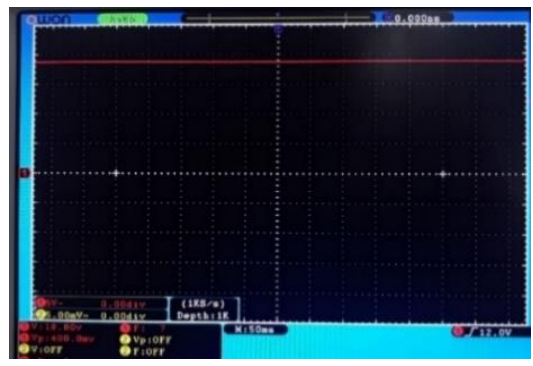

Gambar 10. Gelombang keluaran penyearah gelombang penuh

dapat dilihat tinggi gelombang hasil penyearahan adalah 3,8 div pada skala pengukuran $50 \mathrm{~V} /$ div, maka dapat diketahui nilai tegangan puncak gelombang tersebut yang digunakan untuk memicu IGBT daya adalah sebesar :

$$
\begin{aligned}
\mathrm{V} & =3,8 \mathrm{div} \times 50 \mathrm{~V} / \mathrm{div} \\
& =190 \text { Volt DC }
\end{aligned}
$$

Berdasarkan Gambar 10, bentuk tegangan yang lurus dengan besar tegangan 190 Volt DC sudah sesuai dengan perancangan untuk menyuplai tegangan DC yang dibutuhkan inverter fullbridge resonansi parallel Sedangkan gelombang keluaran inverter fullbridge dapat dilihat pada Gambar 11.

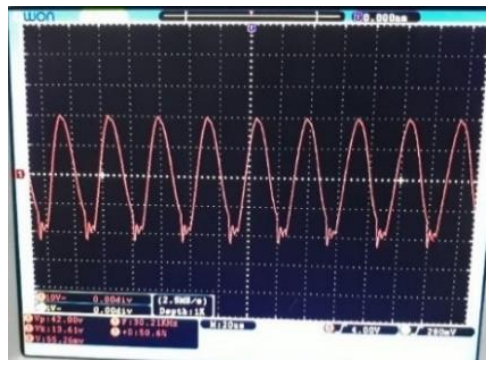

Gambar 11. Gelombang keluaran penyearah gelombang penuh

Berdasarkan pada Gambar 11 dapat diketahui bahwa tinggi puncak gelombang adalah 4,0 div. Pengukuran yang dilakukan pada skala 10 Volt/div. Maka dari data tersebut dapat diketahui tegangan maksimal pada kapasitor dan induktor adalah sama, yaitu

$$
\begin{aligned}
& \mathrm{Vpp}=4,0 \operatorname{div} \times 10 \mathrm{~V} / \operatorname{div} \times 10=400 \text { Volt } \mathrm{AC} \\
& \mathrm{Vp}=400: 2=200 \text { Volt } \mathrm{AC}
\end{aligned}
$$

Dari data dan perhitungan tersebut dapat diketahui bahwa tegangan peak to peak resonansi adalah berbeda, pada perhitungan tegangan output yang di hasilkan adalah

$$
\mathrm{Vm}=\sqrt{2} \times 135 \text { Volt }=190,91 \text { Volt } \mathrm{AC}
$$

sedangkan pada pengukuran di dapatkan nilai tegangan keluaran sebesar 200 Volt AC perbedaan ini di karenakan pada saat pengujian, gelombang bergerak melebar ke atas dan ke bawah. Sehingga sewaktu pengambilan gambar pada oscilloscope, gambar yang tersimpan adalah gambar gelombang yang terbesar

\subsection{Pengujian Aplikasi}

\subsubsection{Pengujian Variasi Frekuensi terhadap Perubahan Suhu}

Pengujian variasi frekuensi terhadap perubahan suhu di lakukan untuk mengetahui pengaruh kenaikan frekuensi terhadap kecepatan penambahan panas. Pengukuran penambahan panas ini dilakukan dengan menggunakan sensor thermocouple. Frekuensi resonan yang di gunakan yaitu $30 \mathrm{kHz}, 35 \mathrm{kHz}, 40 \mathrm{kHz}$, dan $45 \mathrm{kHz}$.

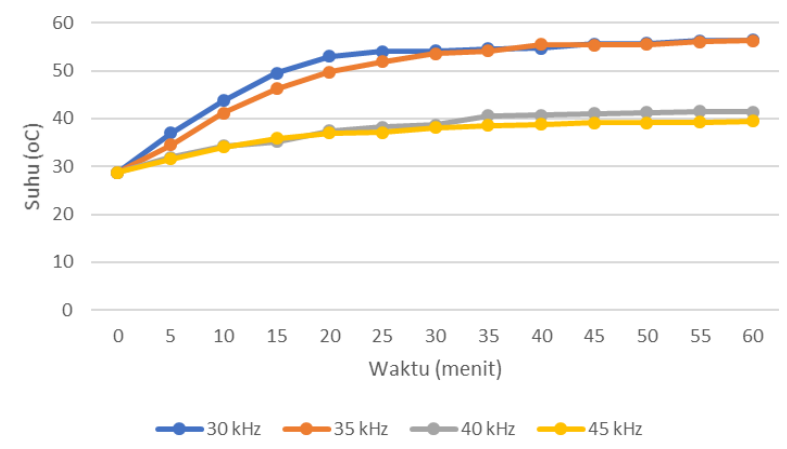

Gambar 12. Grafik perubahan daya terhadap variasi duty cycle frekuensi resonansi

Berdasarkan gambar 12 Dapat diketahui bahwa suhu maksimal terbesar yang dapat di capai dalam waktu 60 menit di dapat pada frekuensi $30 \mathrm{kHz}$ yaitu sebesar 56.40 ${ }^{0} \mathrm{C}$ dan suhu terkecil yang di capai dalam waktu 60 menit di dapat pada frekuensi $45 \mathrm{kHz}$ yaitu sebesar $39.46{ }^{\circ} \mathrm{C}$

\subsubsection{Pengujian Variasi Frekuensi terhadap Perubahan Arus}

Pengujian variasi frekuensi terhadap perubahan arus di lakukan untuk mengetahui karakteristik perubahan arus 
sistem terhadap perubahan frekuensi resonansi. Berikut data pengujian perubahan arus terhadap variasi frekuensi resonansi :

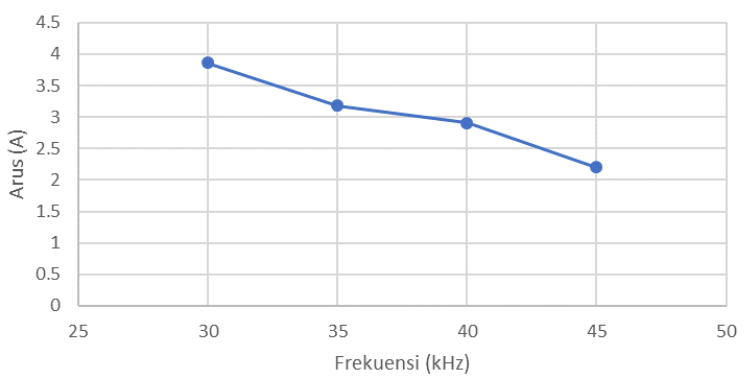

Gambar 13. Grafik perbandingan perubahan arus pada variasi duty cycle tiap frekuensi resonansi

Berdasarkan gambar 13 Dapat diketahui bahwa setiap perubahan frekuensi memiliki perubahan arus yang berbeda-beda. Hal ini di sebabkan oleh adanya efek kulit (skin effect). Pada frekuensi yang tinggi, effek kulit akan semakin signifikan. effek kulit akan menyebabkan arus cenderung mengalir pada permukaan konduktor sehingga konsentrasi arus yang mengalir pada konduktor sistem terdapat pada permukaan konduktor yang berarti luas permukaan efektif konduktor yang dilewati arus akan semakin kecil sehingga akan mengakibatkan bertambahnya nilai resistansi sistem sehingga nilai arus yang mengalir pada sistem akan semakin kecil Hal ini sesuai dengan persamaan efek kulit :

$R_{a c}=R_{d c}+R_{s e}=R_{d c}\left(1+F_{s e}\right)$

dengan:

$\mathrm{R}_{\mathrm{a} \mathrm{c}}=$ Tahanan $\mathrm{AC}(\mathrm{ohm})$

$\mathrm{R}_{\mathrm{dc}}=$ Tahanan DC (ohm)

$\mathrm{R}_{\mathrm{sc}}=$ Tahanan skin efek (ohm).

$\mathrm{F}_{\mathrm{se}}=$ Faktor skin effect

Besarnya faktor skin efek sendiri diperoleh dari persamaan:

$\mathrm{F}_{\mathrm{se}}=\mathrm{d} / \delta$

dengan:

$\mathrm{F}_{\mathrm{se}}=$ Faktor skin efek .

$\mathrm{D}=$ Diameter konduktor $(\mathrm{mm})$.

$\Delta=$ kedalaman kulit $(\mathrm{mm})$.

Dan besarnya kedalaman kulit sendiri diperoleh dari persamaan:

$$
\delta=\sqrt{\frac{\rho}{\pi \mu \mathrm{f}}}
$$

dengan:

$\delta=$ kedalaman kulit $(\mathrm{mm})$.

$\mu=$ Permeabilitas Bahan $(\mathrm{H} / \mathrm{m} 0$

$\mathrm{f}=$ Frekuensi $(\mathrm{Hz})$

$\rho=$ Resistifitas

Dari persamaan 4.1, 4.2, dan 4.3 dapat diketahui bahwa semakin besar frekuensi maka nilai resistansi sistem akan semakin besar yang menyebabkan arus pada sistem semakin mengecil

\subsubsection{Pengujian Variasi Frekuensi terhadap Perubahan Daya}

Pengujian ini dilakukam untuk mengetahui perubahan daya yang terjadi pada saat frekuensi inverter dirubah. Frekuensi yang di gunakan yaitu $30 \mathrm{kHz}, 35 \mathrm{kHz}, 40 \mathrm{kHz}$, dan $45 \mathrm{kHz}$. Parameter yang di rubah dalam pengujian ini hanyalah kapasitor resonan, sedangkan nilai induktor yang juga berfungsi sebagai kumparan penginduksi tidak di rubah. Pengujian dilakukan pada tegangan $135 \mathrm{~V}$ AC 50 $\mathrm{Hz}$

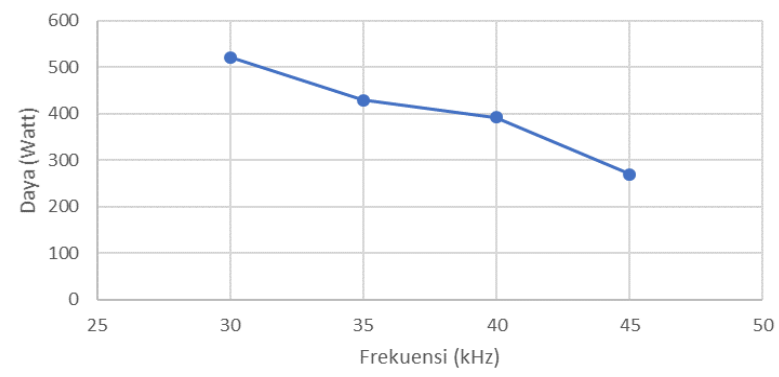

Gambar 14 Grafik perbandingan perubahan arus pada variasi duty cycle tiap frekuensi resonansi

Berdasarkan gambar 14 Dapat diketahui bahwa setiap perubahan frekuensi memiliki perubahan daya yang berbeda-beda. Hal ini di sebabkan oleh adanya efek kulit (skin effect). Pada frekuensi yang tinggi efek kulit akan semakin signifikan. Efek kulit akan mengakibatkan arus cenderung mengalir pada permukaan konduktor sehingga konsentrasi arus terbesar yang mengalir pada konduktor sistem terdapat pada permukaan konduktor yang berarti luas permukaan efektif konduktor yang dilewati arus akan semakin kecil. Hal ini telah sesuai dengan persamaan 4.1, 4.2 dan 4.3 dimana semakin tinggi frekuensi resonansi maka akan mengakibatkan bertambahnya nilai resistansi sistem sehingga nilai arus yang mengalir pada sistem akan semakin kecil yang berakibat pada semakin rendahnya daya pada sistem. Jadi dalam hal ini semakin tinggi frekuensi yang digunakan maka efek kulit akan semakin signifikan sehingga mengakibatkan semakin rendahnya daya pada sistem.

\section{Kesimpulan}

Inverter Frekuensi tinggi sebagai suplai pemanas pada oven bekerja pada frekuensi $30 \mathrm{kHz}, 35 \mathrm{kHz}, 40 \mathrm{kHz}$, dan $45 \mathrm{kHz}$, ke empat frekuensi tersebut di pilih karena berada di atas batas ambang pendengaran manusia yaittu $20 \mathrm{kHz}$. Frekuensi resonansi mempengaruhi suhu yang di hasilkan, dimana semakin kecil frekuensi resonansi yang di berikan maka besar suhu yang di hasilkan akan semakin besar. Arus keluaran inverter dapat diatur dengan mengatur frekuensinya. Arus maksimal dicapai ketika frekuensi 
resonan $30 \mathrm{kHz}$ yaitu sebesar $3.86 \mathrm{~A}$ dan turun ketika frekuensi dinaikkan atau diturunkan. Daypa keluaran inverter dapat diatur dengan mengatur frekuensinya. Daya maksimal dicapai ketika frekuensi resonan $30 \mathrm{kHz}$ yaitu sebesar 521.1 watt dan turun ketika frekuensi dinaikkan atau diturunkan

\section{Referensi}

[1]. A. Nurhidayat, T. Mesin, U. Surakarta, K. Surakarta, And J. Barat, "Rekayasa Alat Pengering Untuk Meningkatan Produktivitas Ukm Emping Mlinjo," Semin. Nas. Sains Dan Teknol., Pp. 37-41, 2010.

[2]. A. S. I. Akbar, "Rancang Bangun Prototype Sistem Pemanggang Kue ( Oven ) Otomatis Dengan Menggunakan Mikrokontroler Avr Atmega 8535," Dielektrika, Vol. 1, No. 2, Pp. 69-81, 2014.
[3]. S. Yudho, P. Ritonga, A. Warsito, And M. Facta, "Perancangan Full Bridge Inverter Resonansi Paralel Sebagai Catu Daya Pemanas Induksi Pada Pipa Pemanas Air," Transient, Vol. 6, 2017.

[4]. A. S. Albert Z.N, Agung Warsito, "Perancangan Modul Inverter Frekuensi Tinggi Sebagai Suplai Pemanas Induksi untuk Aplikasi Pengering Pakaian,"

[5]. P. S. Pratama, A. Warsito, and K. Elektro, "Perancangan Inverter Resonan Seri Frekuensi Tinggi Sebagai Suplai Pemanas Induksi Pada Alat Pemanas Bearing," Eprint Undip, pp. 1-6, 2011.

[6]. Prakoso, Eko Satrio. Perancangan Konverter Arus Searah Zeta Voltage Feedback Menggunakan Ic T1494

[7]. Ginting, Novitasari Br.Perancangan tegangan tinggi dc dengan metode cockroft-walton tipe fullwave

[8]. Suroso, Segal Mancini. Perancangan Inverter Satu Fasa Off-Grid Menggunakan Dspic30f4011 Dengan Kontrol Arus Metode Proportional Resonan 